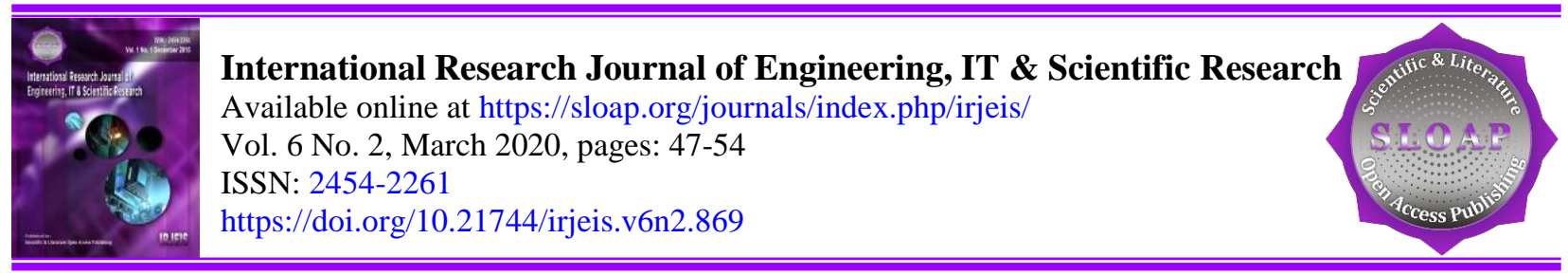

\title{
Relationship Between Length of Leg and Strength of Leg Muscle to Frequency of Straight Kicks
}

\begin{tabular}{|c|c|}
\hline & Agustinus Dei $^{\text {a }}$ \\
\hline Article history: & Abstract \\
\hline $\begin{array}{l}\text { Submitted: } 27 \text { January } 2020 \\
\text { Revised: } 18 \text { February } 2020 \\
\text { Accepted: } 09 \text { March } 2020\end{array}$ & $\begin{array}{l}\text { To be able to increase kick frequency requires anthropometric factors and } \\
\text { adequate physical conditions. Anthropometry that is very important is the } \\
\text { length of the leg and a very important physical condition is the strength of the } \\
\text { leg muscles. For this reason, the length of leg and strength of leg muscles } \\
\text { which is related to the frequency of straight kicks need further investigation. } \\
\text { This study aims to determine the relationship between the length of the leg }\end{array}$ \\
\hline $\begin{array}{l}\text { Keywords: } \\
\text { frequency of the straight kick; } \\
\text { length of the leg; } \\
\text { pencak silat; } \\
\text { relationship; } \\
\text { strength of the leg muscle; }\end{array}$ & $\begin{array}{l}\text { and strength of leg muscle to the trequency of straight kicks. This research is } \\
\text { a correlation study with data collection using tests and measurements. The } \\
\text { population of this research is } 70 \text { male pencak silat at Junior High School of } \\
\text { PGRI-1. From this population, } 33 \text { peoples were chosen by random sample } \\
\text { selection. The test is a measurement of leg length using an antrophometer } \\
(\mathrm{cm}) \text {. Measurement of leg muscle strength with leg dynamometer }(\mathrm{kg}) \text {, and } \\
\text { frequency of straight kick measurement using a hand box and stopwatch by } \\
\text { measuring the number of kicks in one minute. Data analysis was performed } \\
\text { using Pearson correlation and multiples regression. Based on the analysis at } \\
\text { the } 5 \% \text { significance level, it shows that there is no relationship between the } \\
\text { length of leg and frequency of straight kick with the correlation coefficient } \mathrm{r} \\
=-0.279 \text { and } \mathrm{p}=0.115 \text {. There is a significant relationship between the } \\
\text { strength of leg muscle and frequency of straight kick with correlation } \\
\text { coefficient } r=0.803 \text { and } p=0,000 \text {. Multiple regression values } r=0.841 \text { with } \\
p=0,000 \text {. The determining coefficient is } 70.7 \% \text {. This means that there is a } \\
\text { significant relationship between leg muscle strength and leg length and the } \\
\text { frequency of straight kicks. Therefore, it is necessary to consider the length } \\
\text { of leg and strength of leg muscle in determining the frequency of straight. }\end{array}$ \\
\hline
\end{tabular}

International research journal of engineering, IT \& scientific research (C) 2020. This is an open access article under the CC BY-NC-ND license (https://creativecommons.org/licenses/by-nc-nd/4.0/).

\section{Corresponding author:}

Agustinus Dei,

Program of Physical Education, Health, and Recreation, FPOK IKIP PGRI Bali, Denpasar, Indonesia.

Email address: desegu17@gmail.com

a Program of Physical Education, Health, and Recreation, FPOK IKIP PGRI Bali, Denpasar, Indonesia 


\section{Introduction}

Pencak silat is one of the sports heritage of the Indonesian nation which needs to be preserved and developed. Pencak silat is a way of self-defense that is adapted to the surrounding natural conditions that have developed in prehistoric times. Pencak silat is a genuine martial art of Indonesia to avoid all disasters (Sudiana, 2009). In 1975 the Executive Board of the Indonesian Pencak Silat Association (PB IPSI) defined that, pencak silat is the result of the cultivation of the archipelago with the characteristics in each region. The aim is to maintain the existence and integrity of the local area (Rachman, 2008).

In increasing achievement, pencak silat training needs various things including the ability to move, physical condition, tactics and mental. Basic techniques need to be mastered first to improve martial arts achievement. In pencak silat there are various streams so that the names and basic moves are different in each stream. But basically, the form of the style is almost the same. Some basic skills in pencak silat according to the National IPSI standard include horses, pairs of attitudes, and patterns of steps, defenses, avoidance, attacks, and catches.

Pencak silat competition has a difference with other martial arts because it must display the attitude of the tide, the pattern of steps, attack, and back to the tide. All methods must occur in play every round. Techniques to achieve optimal results can be using punches, kicks, greeting techniques, cutouts, or falling with catches.

An attack with an incoming leg on the target without being blocked by an opponent's defense, avoidance or evasion will get two points. According to the IPSI National Conference (2012), assessed foot attacks are attacks that hit the target by using foot attack techniques (in any form), strong and steady, not accompanied by catches/handles, without being blocked by rebuttal or hindrance and horse support- a horse, or a good fulcrum, good range and correct trajectory. Attacks with legs and feet consist of kicks, strokes, snouts, and clippings. Kick in Pencak Silat consists of several types namely straight kicks, sickle kicks, T kicks, and back kicks.

The kick technique skills in pencak silat are greatly influenced by the quality of the leg muscles of the pencak silat player. To be able to do the kick technique well it takes the element of strength and speed of the muscle groups supporting the movement. Of the most dominant muscle groups supporting the kick, movement is the leg muscles. Therefore, the provision of training applied to the fighter is very appropriate when focused on the leg muscles, by not ignoring other supporting muscles. Leg muscle strength functions as a buffer of body weight, jumping, walking, running, kicking, and escorting (Harsono, 2013).

Muscle strength can also be interpreted as the maximum strength of the muscles supported by cross-sectional which is the muscle to hold the maximum load on the tendon. In muscle contraction produces tension and requires strength (Ariani \& Putu, 2011). Rapid strength or power is the ability of muscles to exert maximum strength in a very short time (Nala, 2011). Furthermore, Sandi \& Parwata (2018), stated that in exercising, several factors must be considered, including physical, technical, mental conditions, facilities and infrastructure, age, anthropometry, environmental factors, and others. Environmental factors are a very important role in sports, especially the temperature and relative humidity of the air (Sandi 2014; Sandi et al., 2017). Research results from Sandi et al. (2016), that $40 \%$ relative humidity inhibits the increase in pulse, body temperature, and blood lactic acid levels in exercise. Furthermore, the research results of Sandi et al. (2017), found that $40 \%$ of the relative humidity of the air inhibits the decrease in body fluids compared to $60 \%$ of the relative humidity during exercise. Another factor that is no less important is the mastery of biomechanics. According to Sandi et al. (2020), a trainer will not be successful in training if he does not know the principles of the lever system, the location of the body's center of gravity, momentum, and impulses.

Kick is a movement that is done by using the foot and become a very important technique because its strength is far greater than the hand, and the use of kicks is not only done during the fight, but the kick is also done when doing movement moves (TGR art), where the movement this requires a biomotor component of speed, strength, and balance. Besides that, it also requires good mastery of motion techniques, mastery of distance and the right timing for the kick to be effective.

One of the kicks that are often used in training or competition is a straight kick. The more kicks taken by athletes and their targets following applicable pencak silat rules will get a higher score. Therefore, the speed or number of kicks in time is very influential on the value that will determine the athlete's victory. Kick speed that produces kick frequency is influenced by internal factors and training factors provided to a fighter (Sudiana, 2009).

The frequency of the kick is affected by the length of the leg. The length of the limbs involves the bones and muscles of the limbs that form both the lower limbs and the upper limbs. Leg-forming bones include leg bones, tibia and fibula limbs and femur bones (Syarifuddin, 2012). The leg-forming muscles involved when implementing the 
pencak silat straight kick consist of several muscle groups, namely the groin muscles, upper leg muscles, lower leg muscles, and the feet muscles (Sudiana, 2009).

The difference in muscle strength, proportions and the size of the cross-section of muscles in the body for men and women of the same age will be different. Thus the muscle strength is also different. The different values of muscle strength and muscle mass in each muscle group are also different. Age also affects kick speed, because all biomotor components are influenced by a person's age. From direct observations of researchers in the field at a glance it can be seen that with the same age and gender, the speed of the student kick is different. In pencak silat, especially in making straight kicks, several combinations of movements must be mastered to be able to kick well and quickly. Biomotor components needed in pencak silat kicks are speed, endurance, strength, balance, coordination, flexibility, and explosive power. If these components are not met then it is difficult to do a straight kick (Tamat, 2002).

A straight kick is an attack that uses one foot, where the trajectory is forward with the body facing forward. In this kick, the use is the base of the inner toes with the target of the solar plexus and the chin (Lubis \& Wardoyo, 2014). There are four movements when doing a straight kick. First; head movements facing the target, second; perpendicular body movements to maintain balance when releasing the kick to return to the next, third; upper limb movements in rhythm with the movements of the body and upward footwork, one hand is in front of the chest with elbows bent and the other hand straight down, alternating swinging movements between the left and right legs, fourth; movements of the limbs do a straight kick with maximum speed and strength, one foot as a pedestal and the other foot attacks, its trajectory going forward with the body facing forward, its use is the base of the inner toes with the target of the solar plexus and chin (Bakti Negara, 2007).

The purpose of this study was to determine the relationship between the length of the leg and strength of the leg muscle to the frequency of the straight kicks in pencak silat athletes of PGRI-1 Junior High School in Denpasar. The results of this study are expected to add insight into sports science specifically in the relationship between leg length and leg muscle strength to the frequency of straight kicks as a parameter to determine the level of development of athletes undergoing an exercise program. Another goal is to provide scientific data for coaches in improving athlete achievement (Genty et al., 1989; Burnett \& Rickerby, 1987; Deschrijver \& Kerre, 2003).

\section{Materials and Methods}

This research is a descriptive study. The study population was 70 students from Junior High School -PGRI-1 Denpasar aged 14-15 years. Of these 33 people were selected as samples that fit the inclusion, exclusion, and group out criteria. The study was conducted at SMP PGRI-1 Denpasar for two days. The independent variables are leg length (X1) and leg muscle strength (X2), while the dependent variable is straight kick frequency (Y). The research instrument used in the form of a leg length measuring instrument using a Japanese super brand antrophometer, leg muscle strength used a leg brand dynamometer made in Japan and kick frequency using a stopwatch brand Seiko. Research data were collected by direct measurement of the study sample. The research data were analyzed using the Pearson correlation test to analyze the relationship between leg length and kick frequency and the relationship between leg muscle strength and kick frequency. Furthermore, a multiple regression test was performed to determine the simultaneous relationship between leg length and leg muscle strength and the frequency of straight kicks. The strength of the relationship is expressed by the correlation coefficient and the relationship is stated by the significance value $\mathrm{p}$. The limit of significance used is 0.05 .

\section{Results and Discussions}

\subsection{Result \\ Research characteristics}

The characteristics of the research concern the characteristics of the research subjects, and the characteristics of the results of the study. The characteristics of the research subjects from the data collected were age, weight, and height. While the characteristics of the results of the study are leg length, leg muscle strength, and kick frequency. The data is shown in Table 1.

Dei, A. (2020). Relationship between length of leg and strength of leg muscle to frequency of straight kicks. International Research Journal of Engineering, IT \& Scientific Research, 6(2), 47-54. https://doi.org/10.21744/irjeis.v6n2.869 
Table 1

Characteristics of subjects

\begin{tabular}{lllll}
\hline Characteristics & N & Minimum & Maximum & Mean \pm SD \\
\hline Age (years) & 33 & 14,00 & 15,00 & $14,59 \pm 0,50$ \\
Weight (kilograms) & 33 & 42,00 & 57,00 & $49,24 \pm 2,92$ \\
Height (centimeters) & 33 & 140,00 & 159,00 & $154,03 \pm 3,51$ \\
Length of Leg (centimeters) & 33 & 85,20 & 93,90 & $89,62 \pm 2,08$ \\
Strength of Leg Muscle (kilograms) & 33 & 21,50 & 39,50 & $29,32 \pm 3,74$ \\
Frequency of kick (times per minute) & 33 & 24,00 & 34,00 & $28,73 \pm 2,99$ \\
\hline
\end{tabular}

Note: $\mathrm{N}=$ number of samples, $\mathrm{SD}=$ standard deviation

The relationship between the length of leg and strength of leg muscle to the frequency of the kick

Data from the analysis of the relationship between the length of leg and frequency of kick and between the strength of leg muscle and frequency of kick analyzed by the Pearson correlation test are shown in Table 2.

Table 2

Correlation between research variables

\begin{tabular}{llclc}
\hline Research variable & & Length of Leg & \multicolumn{2}{c}{ Strength of Leg Muscle } \\
\hline Frequency of Straight Kick & $\mathrm{r}$ & $-0,279$ & $\mathrm{r}$ & 0,803 \\
& $\mathrm{p}$ & 0,115 & $\mathrm{p}$ & 0,000 \\
& $\mathrm{n}$ & 33 & $\mathrm{n}$ & 33 \\
\hline
\end{tabular}

Note: $r=$ correlation coefficient, $\mathrm{p}=$ significance value, $\mathrm{n}=$ number of samples

From Table-2 it is found that there is no relationship between leg length with straight kick frequency with correlation coefficient $r=-0.279$ and $p=0.115(p>0.05)$, there is a significant relationship between leg muscle strength and straight kick frequency with $\mathrm{r}=0.803$ and $\mathrm{p}=0.000(\mathrm{p}<0.05)$.

Simultaneous relationship between the length of leg and strength of leg muscle to the frequency of straight kicks

Next will be tested the relationship between leg length and leg muscle strength of students participating in pencak silat extracurricular SMP PGRI-1 Denpasar. Statistical test results using multiple regression analysis can be seen in Table 3.

Table 3

Analysis of the relationship between the length of the leg (X1) and strength of leg muscle (X2) against straight kick frequency $(\mathrm{Y})$

\begin{tabular}{lllll}
\hline Correlation & $\mathrm{r}$ & $\mathrm{r}^{2}$ & $\mathrm{p}$ & Contribution (\%) \\
\hline $\mathbf{X}_{\mathbf{1}} \mathbf{X}_{\mathbf{2}} \mathbf{Y}$ & 0,841 & 0,707 & 0,000 & 70,7 \\
\hline
\end{tabular}

Note: $\mathrm{r}=$ correlation coefficient, $\mathrm{p}=$ significance, $\%=$ percent

Based on the results of the analysis above, the correlation coefficient between the leg length and leg muscle strength on the straight kick frequency is 0.841 , a positive value means the greater the value that affects the greater the value of the result. The simultaneous relationship between leg length and leg muscle strength to the frequency of straight kicks was significant $(\mathrm{p}<0.05)$. Thus there is a significant relationship between leg length and leg muscle strength to the frequency of straight kicks in pencak silat extracurricular students at SMP PGRI-1 Denpasar.

The magnitude of the contribution of the determinant coefficient of the leg length and leg muscle strength to the frequency of the straight kick is obtained by multiplying between $r^{2}$ by $100 \%\left(r^{2} \times 100 \%\right)$. The value of $r^{2}$ is 0.707 , so the contribution of leg length and leg muscle strength to the frequency of straight kicks $(\mathrm{KP})=0.707 \times 100 \%=$ $70.7 \%$. Thus there are as many as $29.03 \%$ influenced by other factors not investigated. 
3.2 Discussion

Research characteristics

Based on Table-1, age ranges from 14-15 years with a mean of $14.58 \pm 0.50$ years. This age is indeed appropriate for junior high school students, considering that students who take extracurricular pencak silat never miss class. Therefore, the age factor will affect leg length, leg muscle strength, and frequency of straight kicks.

The mean height of the subject was $154.03 \mathrm{~cm}$ with a standard deviation of 3.51 centimeters. The minimum height is 140.00 centimeters and the maximum is 159.00 centimeters. This subject is in the mild nutritional mall limit to normal WHO standards which are in the $50^{\text {th }}$ percentile (Soetjiningsih, 2013). So when viewed in terms of height, the subject has no significant nutritional deficiencies and can do activities like most students to influence the frequency of straight kicks.

The mean body weight of the subject was 49.24 kilograms with a standard deviation of 2.92 kilograms. The minimum limit is 42.00 kilograms and the maximum limit is 57.00 kilograms. This value is also in the mild nutritional mall limit up to normal WHO standards taken at the $50^{\text {th }}$ percentile (Soetjiningsih, 2013). Therefore, none of the research subjects lacked significant nutrition when viewed by their body weight. In this weight condition, the subject can carry out the physical activity as usual so that it will affect the frequency of straight kicks.

Both height and weight will affect the nutritional status of the subject by comparison between body weight (kilograms) and height squared (meter squared). This comparison is called the body mass index. Nutritional status as measured by body mass index is influenced by various things including consumption patterns and physical activity. The better the consumption pattern the better the nutritional status and the better the physical activity the better the nutritional status. This is consistent with the results of research Ariyasa et al. (2017). Whether it's age, height, or weight will be closely related to one's fitness. When viewed from the pulse frequency, there is a significant positive correlation between age, height, and weight (Sandi, 2013). This will certainly affect the strength of leg muscles which directly also affects increasing the frequency of straight kicks.

\section{Contribution of the leg length to the kick frequency}

Pearson correlation analysis results show that leg length does not contribute to kick frequency. This is indicated by the correlation coefficient of -0.279 with a value of $p=0.115(p>0.05)$. This shows that there is no significant effect between leg lengths on kick frequency. A negative sign indicates a negative correlation, which means that if the leg length increases the kick frequency will decrease and conversely the kick frequency will increase if the leg length decreases. However, the negative correlation between the two is not significant with $p=0.115(p>0.05)$.

The frequency of the kick is closely related to the kick away in the soccer game. The results of similar studies show that there is no relationship between leg length and the ability to kick a ball in students aged 16-18 years with a correlation coefficient $\mathrm{r}=0.268$ and $\mathrm{p}=0.195$ (Purwanta, 2016). Research that links the relationship between leg length and kick frequency is different from leg length and running speed. If the leg length increases, the running speed will increase, whereas the running speed decreases when the leg length decreases. The results of Maulana (2019), of elementary school students, found that there was a significant relationship between leg length and running speed with a correlation coefficient $r=0.672$ with $\mathrm{p}=0.012$.

The difference between the result of the relationship between the length of the leg and the frequency of the kick and the length of the leg to the running speed is due to the frequency of the kick, the foot takes the target with a higher distance than the shorter leg (Austin et al., 2003; Walsh et al., 2000; Gurney, 2002). Increased distance of the track causes an increase in travel time from the ready to the target. Increasing travel time will reduce kick frequency. When running, the opposite occurs, namely running speed is directly proportional to the length of the leg. This is caused by an increase in leg length causing an increase in the length of the steps which speeds up running.

\section{Contribution of leg muscle strength to kick frequency}

From the results of data analysis using Pearson correlation, it was found that leg muscle strength contributed to kicking frequency. This is indicated by the correlation coefficient of 0.803 with a value of $p=0.000(p<0.05)$. This shows that there is a significant influence between leg muscle strength and kick frequency and positive correlation. If the leg muscle strength increases the kick frequency will increase and if the leg muscle strength decreases the kick frequency will also decrease.

Dei, A. (2020). Relationship between length of leg and strength of leg muscle to frequency of straight kicks. International Research Journal of Engineering, IT \& Scientific Research, 6(2), 47-54. https://doi.org/10.21744/irjeis.v6n2.869 
Leg muscle strength is very closely related to leg muscle explosive power, where the higher the leg muscle strength, the higher the leg muscle explosive power. The results of Maulana (2019), which was conducted on the ability to kick a ball in elementary school students in Gowa, obtained a correlation coefficient of 0.521 which states there is a positive correlation between leg muscle strength and the ability to kick a ball. This means that the higher the leg muscle strength, the higher the ability to kick the ball. Research has also been conducted by Putri et al. (2019), found that there is a relationship between leg muscle strength and running speed with a positive correlation.

In principle, leg muscle strength is the ability of muscles to generate tension over a load. If the soccer player's leg muscle strength is adequate when kicking the ball, then it will certainly contribute to providing maximum results. Fahkruzzaman (2015), found that there was a relationship between leg muscle explosive power and kicking ability of the SSB Aneuk Rencong Banda Aceh player with a correlation coefficient $r=0.540$. The results of a similar study also carried out by Ash'ari (2017), there is a significant relationship between the leg muscle explosive power and the results of the dollyo chagi kick in male athlete taekwondo Bandar Lampung.

\section{Contribution of leg length and leg muscle strength to kick frequency}

In this hypothesis, the simultaneous relationship between leg length and leg muscle strength is tested for the frequency of kicks. It has been explained that the correlation coefficient between leg muscle strength and kick frequency is greater than the correlation coefficient between limb length and kick frequency, which is $\mathrm{r}=0.803$ compared to $r=-0.279$. This means that the two are opposite so that the simultaneous correlation between leg length and leg muscle strength to the frequency of a straight kick does not greatly increase the correlation coefficient. If we see the simultaneous correlation coefficient of leg length and leg muscle strength get $\mathrm{r}=0.841 \mathrm{with} \mathrm{p}=0.000$, it means that there is a very strong and significant relationship between leg length and leg muscle strength.

Both leg length and leg muscle strength together determine relationships so that the determining coefficient can be calculated. The magnitude of the contribution of the determinant coefficients of these two independent variables to the frequency of straight kicks is obtained by multiplying $\mathrm{r}^{2}$ by $100 \%$, so that the magnitude of the contribution of leg length and leg muscle strength to the frequency of straight kick $=0.707 \times 100 \%=70.7 \%$. So the two variables both leg length and leg muscle strength had an impact of $70.7 \%$. It appears that there were as many as $29.3 \%$ of other factors that helped determine the frequency of straight kicks that were not examined in this study (Paul et al., 2012; Hasselgren et al., 2011; Rittweger et al., 2000; Paul et al., 2012). Possible factors that determine the frequency of a straight kick are the type of training that was followed previously, heredity, a physical condition when collecting data, and environmental factors. If all of these factors are involved in further research, they will get a higher determinant coefficient.

\section{Conclusion}

The results showed; there is no significant relationship between leg length and kick frequency and there is a significant relationship between leg muscle strength and kick frequency. There is a significant simultaneous relationship between leg length and leg muscle strength to the frequency of straight kicks with a contribution of $70.7 \%$.

\section{Suggestions}

It is expected that sports teachers, coaches, and sports coaches especially pencak silat look for pesilat seeds to pay attention to the strength of leg muscles, to produce an increased frequency of straight kicks. Besides that, it is also recommended to train leg muscle strength to increase kick frequency. Another more in-depth study of leg muscle strength and leg length is recommended for the frequency of straight kicks.

\section{Conflict of interest statement}

The author declared that he has no competing interests.

\section{Statement of authorship}

The author has a responsibility for the conception and design of the study. The author has approved the final article.

\section{Acknowledgments}

I am grateful to two anonymous reviewers for their valuable comments on the earlier version of this paper. 


\section{References}

Ariani, T., \& Putu, L. (2011). Dasar-dasar Kepelatihan Olahraga. Singaraja: Universitas Pendidikan Ganesha.

Ariyasa, G., Sandi, N., \& Murna, I. M. (2017). Hubungan Antara Pola Konsumsi dan Aktivitas Fisik terhadap Status Gizi pada Lansia Di Panti Sosial Tresna Werdha Jara Mara Pati Buleleng. Sport and Fitness Journal, 5(2), 124132.

ASY'ARI, A. F. (2017). Hubungan antara panjang tungkai dan power tungkai dengan hasil tendangan dollyo chagi pada atlet putra sabuk kuning usia 18 tahun taekwondo thjc Bandar Lampung.

Austin, M. S., Hozack, W. J., Sharkey, P. F., \& Rothman, R. H. (2003). Stability and leg length equality in total hip arthroplasty. The Journal of arthroplasty, 18(3), 88-90. https://doi.org/10.1054/arth.2003.50073

Bakti Negara, 2007. Pedoman Dasar Persatuan Seni Pencak Silat. Denpasar, Pustaka Nayotama

Burnett, P. J., \& Rickerby, D. S. (1987). The relationship between hardness and scratch adhession. Thin solid films, 154(1-2), 403-416. https://doi.org/10.1016/0040-6090(87)90382-8

Deschrijver, G., \& Kerre, E. E. (2003). On the relationship between some extensions of fuzzy set theory. Fuzzy sets and systems, 133(2), 227-235. https://doi.org/10.1016/S0165-0114(02)00127-6

Fakhruzzaman, D. (2015). Hubungan Antara Panjang Tungkai Dan Daya Ledak Otot Tungkai Terhadap Kemampuan Menendang Pada Pemain Ssb Aneuk Rencong Banda Aceh Tahun 2010. Jurnal Ilmiah Mahasiswa Pendidikan Jasmani, Kesehatan dan Rekreasi, 1(2).

Genty, B., Briantais, J. M., \& Baker, N. R. (1989). The relationship between the quantum yield of photosynthetic electron transport and quenching of chlorophyll fluorescence. Biochimica et Biophysica Acta (BBA)-General Subjects, 990(1), 87-92. https://doi.org/10.1016/S0304-4165(89)80016-9

Gurney, B. (2002). Leg length discrepancy. Gait \& posture, 15(2), 195-206. https://doi.org/10.1016/S09666362(01)00148-5

Harsono, (2013). Choaching dan Aspek-aspek Psikologi dalam Choaching. CV: Tambak Kusuma Bandung.

Hasselgren, L., Olsson, L. L., \& Nyberg, L. (2011). Is leg muscle strength correlated with functional balance and mobility among inpatients in geriatric rehabilitation?. Archives of gerontology and geriatrics, 52(3), e220-e225. https://doi.org/10.1016/j.archger.2010.11.016

Lubis, J., \& Wardoyo, H. (2014). Pencak silat. RajaGrafindo Persada.

Maulana, A. A. (2019). Kontribusi kekuatan otot tungkai, panjang tungkai dan keseimbangan terhadap kemampuan menendang bola pada permainan sepakbola murid SD Negeri Sungguminasa IV Kabupaten Gowa (Doctoral dissertation, Universitas Negeri Makassar).

Nala, N. (2011). Prinsip Pelatihan Fisik Olahraga. Denpasar.

Paul, S. S., Canning, C. G., Sherrington, C., \& Fung, V. S. (2012). Reproducibility of measures of leg muscle power, leg muscle strength, postural sway and mobility in people with Parkinson's disease. Gait \& posture, 36(3), 639642. https://doi.org/10.1016/j.gaitpost.2012.04.013

Paul, S. S., Canning, C. G., Sherrington, C., \& Fung, V. S. C. (2012). Reduced muscle strength is the major determinant of reduced leg muscle power in Parkinson's disease. Parkinsonism \& related disorders, 18(8), 974977. https://doi.org/10.1016/j.parkreldis.2012.05.007

Purwanta, Y. (2016). Hubungan panjang tungkai dan kekuatan otot tungkai dengan jauhnya tendangan dalam permainan sepakbola pada pemain ps romberz bantul usia 16-18 tahun. Pendidikan Jasmani Kesehatan dan Rekreasi, 1(2).

Putri, R. F. D., Widodo, S., \& Adjie, R. M. S. (2019). Hubungan Panjang Tungkai Dan Kekuatan Otot Tungkai Dengan Kecepatan Lari 60 Meter (Studi pada Pemain Sepak Bola Diklat Diponegoro Muda PS UNDIP) (Doctoral dissertation, Faculty of Medicine).

Rachman, H. (2008). Sejarah dan Perkembangan Pencak Silat di Indonesia. Jakarta: Pengurus Besar IPSI Padepokan Pencak Silat Indonesia.

Rittweger, J., Beller, G., Ehrig, J., Jung, C., Koch, U., Ramolla, J., ... \& Felsenberg, D. (2000). Bone-muscle strength indices for the human lower leg. Bone, 27(2), 319-326. https://doi.org/10.1016/S8756-3282(00)00327-6

Sandi, I. N. (2013). Hubungan antara tinggi badan, berat badan, indeks massa tubuh, dan umur terhadap frekuensi denyut nadi istirahat siswa SMKN-5 Denpasar. Sport and Fitness Journal, 1(1), 38-44.

Sandi, I. N., Ardana, A. G., Parwata, I. M. Y., \& Teresna, I. W. (2017). Effect of relative humidity on expenditure of body fluids and blood pressure when exercise. International research journal of engineering, IT \& scientific research, 3(2), 114-122.

Sandi, I. N., Ariyasa, I. G., Teresna, I. W., \& Ashadi, K. (2017). Pengaruh Kelembaban Relatif Terhadap Perubahan Suhu Tubuh Latihan. Sport and Fitness Journal.

Dei, A. (2020). Relationship between length of leg and strength of leg muscle to frequency of straight kicks. International Research Journal of Engineering, IT \& Scientific Research, 6(2), 47-54. https://doi.org/10.21744/irjeis.v6n2.869 
Sandi, N. (2014). Pengaruh Suhu dan Kelembaban Relatif Udara Terhadap Penampilan Fisik dalam Olahraga. In Naskah Lengkap Seminar Nasional Integrasi Keanekaragaman Hayati dan Kebudayaan dalam Pembangunan Berkelanjutan. Denpasar (Vol. 27).

Sandi, N., \& Parwata, M.Y. (2018). Lingkungan Olahraga. Yogyakarta: Wahana Resolusi.

Sandi, N., Adiputra, N., Pangkahila, A., \& Adiatmika, P. G. (2016). Relative humidity of 40\% inhibiting the increase of pulse rate, body temperature, and blood lactic acid during exercise. Age (year), 20(18), 0-16.

Sandi, N., Yoda, K., Womsiwor, D., \& Da-Silva, H. (2020). Biomekanika Olahraga. Yogyakarta: Wahana Resolusi.

Soetjiningsih, R. G. (2013). Buku Tumbuh Kembang Anak Edisi 2. Jakarta: Penerbit Buku Kedokteran EGC.

Sudiana, K. (2009). Pedoman Perkuliahan Dasar-Dasar Pencak Silat dan Peraturan Wasit Juri. Singaraja: Jurusan Ilmu Keolahragaan FOK Undiksha.

Syarifudin. (2012). Olahraga dan Kesehatan Untuk Tingkat Menengah Atas. Jakarta: Balai Pustaka.

Tamat, T. (2002). Pelajaran Dasar Pencak Silat, Jakarta: Miswar.

Walsh, M., Connolly, P., Jenkinson, A., \& O'Brien, T. (2000). Leg length discrepancy — an experimental study of compensatory changes in three dimensions using gait analysis. Gait \& posture, 12(2), 156-161. https://doi.org/10.1016/S0966-6362(00)00067-9

\section{Biography of Author}

\begin{tabular}{|l|l|}
\hline Agustinus Dei was born in Sumbawa in 1964. He is a permanent lecturer with the \\
position of Lector in the Sports, Health and Recreation Education Program of IKIP \\
PGRI Bali. The education that has been taken is S1 in Physical Education, S2 in Sport \\
Physiology, and currently completing an S3 in Medical Science Concentration in Sports \\
Physiology at Udayana University. Before becoming a lecturer, he had worked as a \\
senior journalist at Bali Post and had served as vice dean of academic affairs at FPOK \\
IKIP PGRI Bali. \\
Email: desegu17@gmail.com
\end{tabular}

